\title{
PERBANDINGAN IMPLEMENTASI ALGORITMA WELCH- POWELL DAN RECURSIVE LARGEST FIRST DALAM PENJADWALAN MATA KULIAH
}

\author{
Yehezkiel Victorious Ermanto ${ }^{1}$, Yosefina Finsensia Riti' ${ }^{2}$ \\ ${ }_{1,2}$ Program Studi Ilmu Informatika, Fakultas Teknik, Universitas Katolik Darma Cendika \\ Jalan Dr. Ir. H. Soekarno No. 201, Surabaya - Indonesia \\ email: ${ }^{1}$ yehezkiel.ermanto@ student.ukdc.ac.id, ${ }^{2}$ yosefina.riti@ukdc.ac.id
}

\begin{abstract}
ABSTRAK
Salah satu hal penting yang harus dilakukan untuk kelangsungan suatu kegiatan yang baik adalah dengan membuat jadwal, dengan dibuatnya jadwal maka kegiatan yang dilakukan dapat lebih teratur atau terorganisir. Namun jika dalam menyusun suatu penjadwalan perlu diperhatikan untuk menghindari terjadinya tabrakan antar aktivitas, hal ini dapat dicegah dengan menggunakan algoritma dalam pembuatan jadwal seperti algoritma welch-Powell dan rekursif terbesar terlebih dahulu. Diantara kedua algoritma tersebut, penulis ingin membandingkan algoritma mana yang sesuai untuk digunakan dalam penyusunan jadwal seperti untuk perkuliahan di Program Studi Informatika Universitas Katolik Darma Cendika Surabaya untuk semester 2 (dua) dan semester 4 (empat) dimana dua mata kuliah memiliki waktu yang sama dalam satu hari. Dari penelitian yang dilakukan didapatkan hasil algoritma welch-powell lebih cepat dari segi waktu dan lebih ringkas dari segi kompleksitas dibandingkan dengan algoritma rekursif terbesar pertama dan dari pewarnaan graf yang dilakukan diperoleh bilangan kromatik senilai 2 (dua) yang artinya dalam satu hari menggunakan 2 (dua) ruang kuliah berdasarkan kesamaan waktu antara mata kuliah di semester 2 (dua) dan semester 4 (empat), untuk mencegah dampak waktu kelas pada waktu yang bersamaan.
\end{abstract}

Kata Kunci: Penjadwalan, Welch-powell, Recursive largest first

\begin{abstract}
One of the important things to make for the continuity of a good activity is to create schedules, with the creation of a schedule, the activities carried out can be more organized or organized. However, if in putting together a scheduling need to be considered to avoid collisions between activities, this can be prevented by using algorithms in the creation of schedules such as welch-Powell algorithms and recursive largest first. Between the two algorithms, the author wants to compare which algorithms are appropriate to be used in the preparation of a schedule such as for lectures in the Informatics Study Program of Darma Cendika Catholic University for semester 2 and semester 4 where two courses have the same time in one day. From the research conducted obtained the results of welch-Powell algorithm faster in terms of time and more concise in terms of complexity compared to the algorithm recursive largest first and from the coloring of graphs conducted obtained chromatic numbers worth 2, which means in one day used 2 lecture halls based on the similarity of time between courses in semester 2 and semester 4, to prevent the impact of classroom time at the same time.
\end{abstract}

Keywords: Scheduling, Welch-powell, Recursive largest first 


\section{PENDAHULUAN}

Penjadwalan adalah kegiatan yang dilakukan untuk mengalokasikan sumbersumber yang ada dengan tujuan menjalankan tugas-tugas dalam jangka waktu tertentu (Sunarni, Bendi and Alfian, 2017). Penjadwalan juga dapat berarti merupakan salah satu kegiatan yang mengatur sebuah aktivitas sehingga aktivitas yang dilakukan menjadi lebih teratur atau terorganisir sehingga tujuan yang diharapkan dapat tercapai dengan baik pula. Apabila tidak ada penjadwalan maka otomatis sebuah kegiatan yang dilaksanakan akan menjadi kurang maksimal. Salah satu contoh penjadwalan adalah penjadwalan mata kuliah di suatu universitas.

Ada beberapa masalah dalam pembuatan jadwal yang seringkali juga menjadikan hambatan untuk membuat jadwal, yaitu seperti adanya benturan antara waktu kegiatan yang satu dengan waktu kegiatan yang lainnya, sehingga diperlukan sebuah cara untuk dapat membuat sebuah jadwal yang baik tanpa adanya benturan antara kegiatan yang satu dengan yang lainnya.

Salah satu cara yang dapat digunakan adalah dengan menggunaan pewarnaan graf yang merupakan salah satu metode dalam teori graf, dimana terdapat tiga jenis perwarnaan graf yaitu pewarnaan simpul/titik, sisi, dan wilayah, namun yang banyak digunakan dalam membuat sebuah jadwal yang baik adalah menggunakan pewarnaan titik. Menurut Dewi pewarnaan titik/simpul yaitu yaitu memberikan warna yang berbeda pada setiap titik yang bertetangga, sehingga tidak ada dua titik yang bertetangga dengan warna yang sama (Novian Riskiana Dewi, 2020).

Terdapat beberapa algoritma yang dapat digunakan untuk menyelesaikan permasalahan pewarnaan simpul graf, misalnya dengan algoritma welch-powell, algoritma backtracking, dan algoritma recursive largest first (Sianipar, 2014). Dari penerapan algoritma tersebut pada pawarnaan graf didapatkan beberapa hasil dari penelitian yang sudah dilakukan, diantaranya penelitian yang dilakukan oleh Bustan dan Salim yang memberikan kesimpulan bahwa pewarnaan titik dengan menggunakan algoritma welch-powell dapat digunakan dalam menentukan jadwal bimbingan mahasiswa agar tidak bentrok dengan mahasiswa lainnya dan tidak perlu mengantri lama untuk bisa bimbingan dengan dosennya (Bustan and Salim, 2019). Pernyataan yang sama juga diberikan oleh (Mahmudah and Irawati, 2018) dalam penelitiannya mengenai pewarnaan simpul/titik pada graf yang menyatakan bahwa pewarnaan simpul graf dapat diterapkan untuk membantuk jadwal ujian semester.

Penelitian yang juga terkait dengan masalah penjadwalan juga dilakukan oleh Saeful dan Taufik yaitu penerapan coloring graph pada permasalahan penjadwalan yang kurang baik di salah satu posyandu di Kabupaten Sukabumi, dengan menggunakan algoritma vertex coloring graph dan SMS gateway, didapatkan hasil adanya kesalahan dalam penjadwalan seperti bentorkan jadwal imunisasi dapat dicegah, serta dapat membuat sebuah jadwal yang baik dan cepat (Bahri, Saeful; Hidayatulloh, 2018). Kemudian penelitian lain yang berkaitan dengan penjadwalan yang menggunakan algoritma welch-powell untuk membantu dalam penyelesaian permasalahan, seperti penyelesaian permasalahan dalam penjadwalan ujian skripsi pada STMIK Amik Riau, yang kemudian setelah digunakannya algoritma welch-powell, didapatkan hasil jadwal ujian yang diikuti 10 peserta dengan dosen penguji tidak saling tumpang tindih (Harianto and Eiva Fatdha, 2016), selanjutnya ada penelitian untuk menyelesaikan permasalahan dalam 
penjadwalan piket OSIS di SMP Negeri 2 Kemrajen, yang kemudian setelah digunakannya algoritma welch-powell, didapatkan hasil jadwal piket yang terbagi menjadi 7 hari dengan tidak ada jadwal yang saling tumpang tindih (Muflikhudin and Pratama, 2021). Kemudian selanjutnya penelitian yang dilakukan terkait penyelesaian permasalahan jadwal bimbingan mahasiswa yang diadakan oleh Program Studi Pendidikan Sekolah Dasar Universitas Pasifik, kemudian setelah digunakannya algoritma welch-powell, didapatkan hasil 8 kelompok terbagi untuk jadwal bimbingan yang tidak saling tumpang tindih (Bustan and Salim, 2019). Kemudian selanjutnya penelitian yang dilakukan untuk optimasi sistem penjadwalan pada penjadwalan customer service di gerai indosat ooredoo cabang Kuta, dan dengan menggunakan algoritma welch-powell, didapatkan hasil terbentuk 3 tim dengan anggota 4 sampai 5 orang dengan jadwal kerja yang tidak saling tumpang tindih (Hignasari, 2020). Kemudian selanjutnya terdapat penelitian yang dilakukan untuk penyusunan jadwal proposal skripsi di Prodi Pendidikan Matematika UIN Raden Intan Lampung yang masih dilakukan manual dan saling tumpang tindih, kemudian setelah digunakannya algoritma welch-powell, didapatkan hasil bahwa dapat dibentuk 4 kelompok dengan dosen penguji, ketua, sekertaris yang berbeda dan dengan jadwal yang saling tidak tumpang tindih (Novian Riskiana Dewi, 2020). Selain dari penggunaan algoritma welch-powell, terdapat juga penelitian yang menggunakan algoritma recursive largest first seperti yang dilakukan untuk penjadwalan mata kuliah di Univesitas Negeri Makassar Jurusan Matematika yang saling tumpang tindih, dan setelah digunakan algoritma recursive largest first ini, didapatkan hasil berupa jadwal mata kuliah yang tidak saling tumpang tindih (Syam, Ihsan and Asman, 2020).

Masing-masing dari algoritma tersebut mempunyai kelebihan dan kekurangannya, namun pada penelitian ini penulis hendak membandingkan antara algoritma welchpowell dan algoritma recursive largest first dari segi waktu penyelesaian dan kompleksitas algoritma dalam bahasa pemrograman c++ untuk mendapatkan sebuah algoritma yang sesuai dan optimal apabila digunakan untuk membuat sebuah jadwal yang baik, dan menggunakan penjadwalan perkuliahan di Program Studi Ilmu Informatika Universitas Katolik Darma Cendika, Surabaya sebagai sampel pengujian.

\section{METODE PENELITIAN}

Penelitian yang dilakukan adalah dengan menggunakan metode komparatif yang dimana (Sugiyono, 2013) metode komparatif bertujuan untuk membandingkan keberadaan variabel melalui dua sampel atau lebih. Metode komparatif pada penelitian ini digunakan untuk mengetahui perbedaan antara algoritma welch-powell dan algoritma recursive largest first dalam membentuk jadwal pengguaan ruang kuliah di Program Studi Ilmu Informatika Universitas Katolik Darma Cendika, Surabaya.

Tahapan penelitian yang dilakukan

1. Melakukan pendataan dan observasi terakit jadwal mata kuliah apa saja yang ada di Program Studi Ilmu Informatika Universitas Katolik Darma Cendika Surabaya

2. Melakukan pemetaan data yang sudah didapatkan dalam bentuk tabel, graf, dan matriks adjacency.

3. Menerapkan dalam program yang dibuat untuk membandingkan 
kecepatan dan kompleksitas antara kedua algoritma tersebut.

4. Mengumpulkan hasil perbandingan dari algoritma welch-powell dan recursive largest first dalam bentuk tabel.

5. Membuat kesimpulan dari penelitian yang sudah dilakukan.

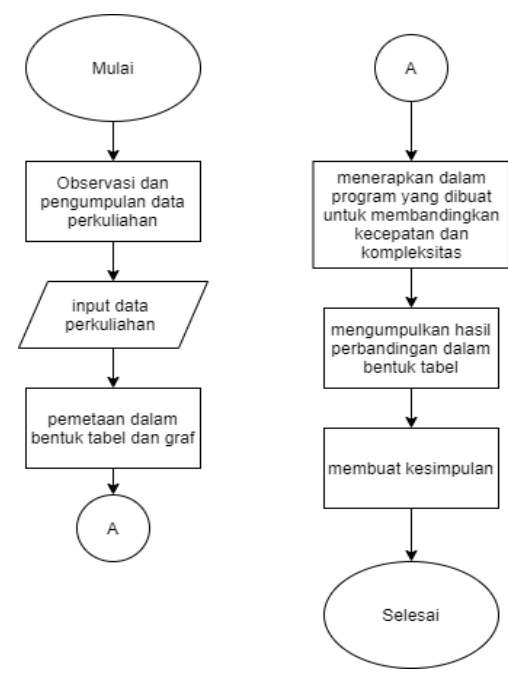

Gambar 1. Diagram Alir Tahapan penelitian

Dari hasil pendataan yang sudah dilakukan didapatkan jadwal mata kuliah di Program Studi Ilmu Informatika Universitas Katolik Darma Cendika untuk semester 2 (dua) dan semester 4 (empat). Total terdapat 14 (empat belas) mata kuliah dengan masing-masing 7 (tujuh) mata kuliah untuk semester 2 (dua) dan semester 4 (empat).

Tabel 1

Jadwal Perkuliahan Program Studi Ilmu Informatika Semester 2

\begin{tabular}{|c|c|c|c|c|}
\hline \multicolumn{5}{|c|}{ 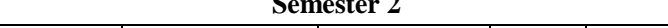 } \\
\hline Kode & Mata Kuliah & $\begin{array}{c}\text { Dosen } \\
\text { Pengampu }\end{array}$ & Jam & Hari \\
\hline IF19206 & $\begin{array}{l}\text { Sistem } \\
\text { Operasi }\end{array}$ & $\begin{array}{l}\text { Stephanus } \\
\text { Surijadarm } \\
\text { a Tandjung, } \\
\text { M.T, Ph.D }\end{array}$ & $\begin{array}{c}10.3 \\
0 \\
\text { s.d. } \\
13.0 \\
0\end{array}$ & $\underset{\mathrm{s}}{\mathrm{Kami}}$ \\
\hline IF19207 & $\begin{array}{c}\text { Algoritma } \\
\text { Pemrograman } \\
\quad 2\end{array}$ & $\begin{array}{c}\text { Ryan } \\
\text { Putranda } \\
\text { Kristianto, } \\
\text { M.Kom }\end{array}$ & $\begin{array}{c}13.0 \\
0 \\
\text { s.d. } \\
15.3 \\
0\end{array}$ & $\begin{array}{c}\text { Selas } \\
\text { a }\end{array}$ \\
\hline IF19208 & $\begin{array}{l}\text { Matematika } \\
\text { Diskrit }\end{array}$ & $\begin{array}{c}\text { Yosefina } \\
\text { Finsensia }\end{array}$ & $\begin{array}{c}09.4 \\
0\end{array}$ & Senin \\
\hline
\end{tabular}

\begin{tabular}{|c|c|c|c|c|}
\hline & & $\begin{array}{c}\text { Riti, } \\
\text { S.Kom, } \\
\text { M.Eng }\end{array}$ & $\begin{array}{c}\text { s.d. } \\
12.1 \\
0\end{array}$ & \\
\hline IF19209 & $\begin{array}{c}\text { Pemrograman } \\
\text { Visual }\end{array}$ & $\begin{array}{l}\text { Edwin } \\
\text { Alexander, } \\
\text { S.Kom, } \\
\text { M.Kom }\end{array}$ & $\begin{array}{c}13.0 \\
0 \\
\text { s.d. } \\
15.3 \\
0 \\
\end{array}$ & Senin \\
\hline IF19210 & $\begin{array}{l}\text { Bahasa } \\
\text { Inggris }\end{array}$ & $\begin{array}{c}\text { Rindrah } \\
\text { Kartiningsi } \\
\text { h, S.S., } \\
\text { M.Si. }\end{array}$ & $\begin{array}{c}11.2 \\
0 \\
\text { s.d. } \\
13.0 \\
0 \\
\end{array}$ & Jumat \\
\hline $\begin{array}{c}\text { UN1800 } \\
3\end{array}$ & $\begin{array}{l}\text { Kepemimpina } \\
\text { n Pribadi }\end{array}$ & $\begin{array}{c}\text { Ir. } \\
\text { Gunawan } \\
\text { Sukianto, } \\
\text { S.M., M.M. }\end{array}$ & $\begin{array}{c}09.4 \\
0 \\
\text { s.d. } \\
11.2 \\
0\end{array}$ & $\begin{array}{c}\text { Selas } \\
\text { a }\end{array}$ \\
\hline $\begin{array}{l}\text { UN1900 } \\
\quad 6\end{array}$ & $\begin{array}{l}\text { Bahasa } \\
\text { Indonesia }\end{array}$ & $\begin{array}{c}\text { Dra. } \\
\text { Yuliana Sri } \\
\text { Purbiyati, } \\
\text { M.Pd. }\end{array}$ & $\begin{array}{c}09.4 \\
0 \\
\text { s.d. } \\
11.2 \\
0\end{array}$ & Rabu \\
\hline
\end{tabular}

Tabel 2

Jadwal Perkuliahan Program Studi Ilmu Informatika

\begin{tabular}{|c|c|c|c|c|}
\hline Kode & $\begin{array}{c}\text { Mata } \\
\text { Kuliah }\end{array}$ & $\begin{array}{c}\text { Dosen } \\
\text { Pengampu }\end{array}$ & Jam & Hari \\
\hline $\begin{array}{c}\text { IF1941 } \\
7\end{array}$ & Teori Graf & $\begin{array}{c}\text { Yosefina } \\
\text { Finsensia } \\
\text { Riti, S.Kom, } \\
\text { M.Eng }\end{array}$ & $\begin{array}{c}10.3 \\
0 \\
\text { s.d. } \\
13.0 \\
0\end{array}$ & $\begin{array}{c}\text { Selas } \\
\mathrm{a}\end{array}$ \\
\hline $\begin{array}{c}\text { IF1941 } \\
8\end{array}$ & $\begin{array}{c}\text { Pemrograma } \\
n \text { Web }\end{array}$ & $\begin{array}{c}\text { Andre } \\
\text { Hartanto, } \\
\text { S.Kom, } \\
\text { M.Kom }\end{array}$ & $\begin{array}{c}08.0 \\
0 \\
\text { s.d. } \\
10.3 \\
0\end{array}$ & Rabu \\
\hline $\begin{array}{c}\text { IF1941 } \\
9\end{array}$ & $\begin{array}{c}\text { Interaksi } \\
\text { Manusia dan } \\
\text { Komputer }\end{array}$ & $\begin{array}{c}\text { Yulia } \\
\text { Wahyuningsi } \\
\text { h, S.Pd, } \\
\text { M.Kom }\end{array}$ & $\begin{array}{c}13.0 \\
0 \\
\text { s.d. } \\
15.3 \\
0\end{array}$ & Senin \\
\hline $\begin{array}{c}\text { IF1942 } \\
0\end{array}$ & $\begin{array}{c}\text { Metode } \\
\text { Numerik }\end{array}$ & $\begin{array}{c}\text { Yulia } \\
\text { Wahyuningsi } \\
\text { h, S.Pd, } \\
\text { M.Kom }\end{array}$ & $\begin{array}{c}10.3 \\
0 \\
\text { s.d. } \\
13.0 \\
0\end{array}$ & $\underset{\mathrm{s}}{\mathrm{Kami}}$ \\
\hline $\begin{array}{c}\text { IF1942 } \\
1\end{array}$ & $\begin{array}{c}\text { Grafika } \\
\text { Komputer } \\
\text { dan } \\
\text { Pengolahan } \\
\text { Citra } \\
\end{array}$ & $\begin{array}{c}\text { Stephanus } \\
\text { Surijadarma } \\
\text { Tandjung, } \\
\text { M.T, Ph.D }\end{array}$ & $\begin{array}{c}11.2 \\
0 \\
\text { s.d. } \\
13.5 \\
0\end{array}$ & Rabu \\
\hline $\begin{array}{c}\text { IF1942 } \\
2\end{array}$ & $\begin{array}{c}\text { Sistem } \\
\text { Multimedia }\end{array}$ & $\begin{array}{l}\text { Edwin } \\
\text { Alexander, } \\
\text { S.Kom, } \\
\text { M.Kom }\end{array}$ & $\begin{array}{c}09.4 \\
0 \\
\text { s.d. } \\
12.1 \\
0\end{array}$ & Senin \\
\hline $\begin{array}{c}\mathrm{IF} 1942 \\
3\end{array}$ & $\begin{array}{l}\text { Dinamika } \\
\text { Kelompok }\end{array}$ & $\begin{array}{l}\text { Ir. Gunawan } \\
\text { Sukianto, } \\
\text { S.M., M.M. }\end{array}$ & $\begin{array}{c}08.5 \\
0 \\
\text { s.d. } \\
10.3 \\
0\end{array}$ & $\underset{\mathrm{s}}{\mathrm{Kami}}$ \\
\hline
\end{tabular}

Dari tabel yang sudah dibuat terdapat beberapa mata kuliah dengan waktu yang 
sama, dan belum ada keterangan ruangan yang dapat digunakan untuk mencegah adanya waktu pemakaian ruangan yang sama dalam satu program studi, sehingga diperlukan penjadwalan ruang kelas minimum yang dapat digunakan.

Kemudian dari tabel tersebut direpresentasikan dalam bentuk graf seperti gambar di bawah ini. Kode dari masing-masing mata kuliah merepresentasikan titik atau vertex dalam graf, kemudian jam dan hari yang sama antara satu mata kuliah dengan mata kuliah lainnya merepresentasikan garis atau $e d g e$ dalam graf.

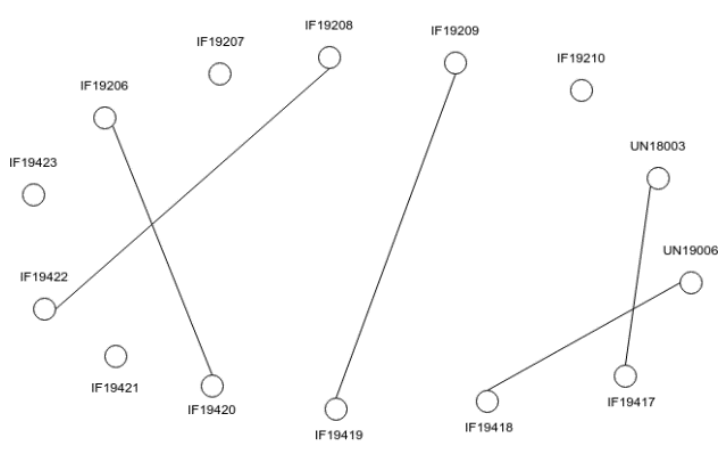

Gambar 2. Graf Jadwal Perkuliahan Program Studi Ilmu Informatika

Kemudian apabila dijadikan matriks adjacency atau matriks ketetanggan menjadi seperti berikut ini.

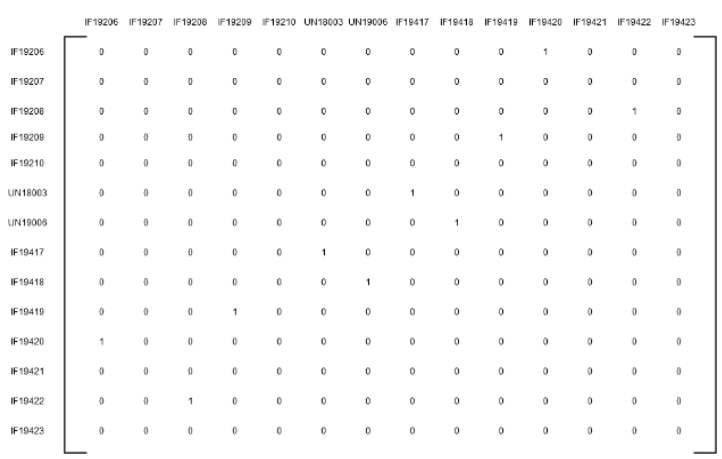

Gambar 3. Matriks Adjacency Jadwal Perkuliahan Program Studi Ilmu Informatika
Algoritma welch-powell merupakan algoritma yang digunakan untuk dalam pewarnaan graf dengan mewarnai simpul dari simpul dengan derajat tertinggi, langkah-langkah yang terdapat dalam algoritma welch-powell adalah sebagai berikut:

1. Mengurutkan simpul-simpul dari $G$ dengan derajat menurun.

2. Menggunakan satu warna untuk mewarnai simpul tertinggi pertama dan simpul-simpul yang tidak bertetangga dengan simpul ini.

3. Mulai lagi dengan mewarnai simpul tertinggi kedua dengan warna lainnya berdasarkan kepada daftar urutan simpul yang sudah dibuat

4. Ulangi melakukan pewarnaan pada simpul sampai semua simpul telah diwarnai (Setia, 2011)

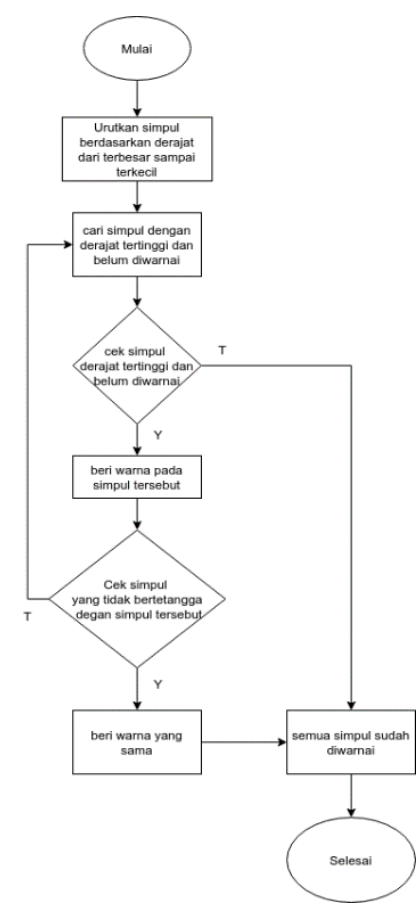

Gambar 4. Diagram Alir Algoritma Welch-powell

Algoritma Recursive Largest First adalah algoritma yang dapat digunakan untuk 
mengatasi masalah pada penjadwalan dengan mengimplementasikannya pada pewarnaan graf. Algoritma ini sesuai untuk graf yang memiliki order besar. Langkah-langkah yang terdapat dalam algoritma ini adalah sebagai berikut:

1. Mendaftar semua semua derajat simpul dan mengurutkan secara menurun atau descending.

2. Dipilih simpul dengan derajat terbesar, kemudian diberikan sebuah warna

3. Mencari simpul yang tidak bertetangga dengan simpul awal sehingga simpul-simpul tersebut menjadi calon simpul yang akan diwarnai sama dengan simpul awal.

4. Seleksi calon simpul sehingga diperoleh simpul yang dapat diwarnai sama dengan warna simpul awal.

5. Ulangi langkah-langkah tersebut hingga semua simpul terwarnai (Sari, Rachmawati and Akbar, 2013)

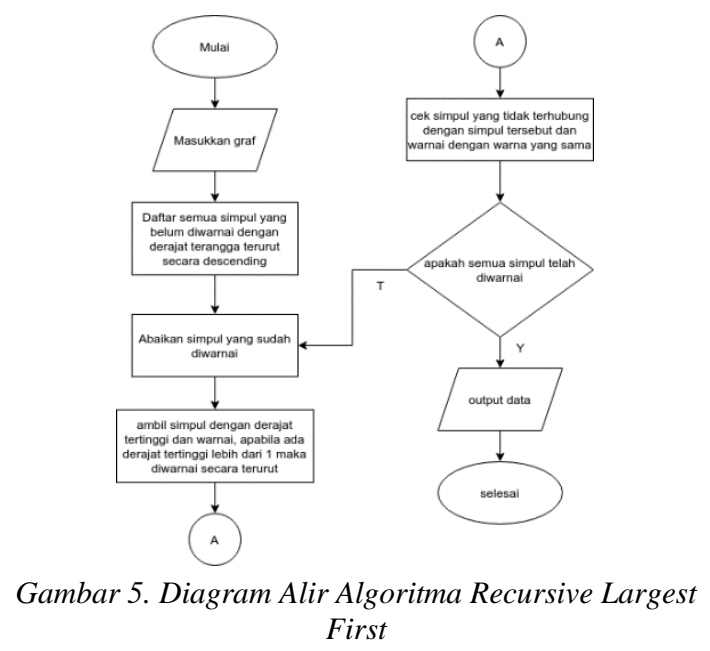

Parameter pemanding yang digunakan dalam penelitian ini ada dua yaitu:

1. Waktu Pengeksekusian Program
Waktu pengeksekusian program menentukan seberapa cepat program berjalan terkait dengan penggunaan fungsi maupuan operator di dalam program tersebut. Ketika melakukan pengujian terhadap sebuah algoritma, semakin singkat waktu yang diperlukan oleh program tersebut semakin baik program tersebut dibuat dan semakin baik pula pengimplementasian algoritma yang digunakan dalam program tersebut.

2. Kompleksitas Program

Kompleksitas program menunjukkan seberapa kompleks atau tingkat kerumitan sebuah program, dapat dilihat dari banyaknya baris kode program yang digunakan.

\section{HASIL DAN PEMBAHASAN}

Dari kegiatan penelitian yang dilakukan menggunakan bahasa pemrograman c++ dan beberapa perangkat pendukung lainnya sebagai berikut:

1. Perangkat Keras (Hardware)
a. Laptop Asus X441BA
b. Prosesor AMD A4-9125
c. RAM 4 GB

2. Perangkat Lunak (Software)

a. Sistem Operasi Windows 10

Home Single Language 64 bit

b. Code Blocks 20.03

Tautan kode program:

https://github.com/yehezkielermanto/com parisonalgorithm 


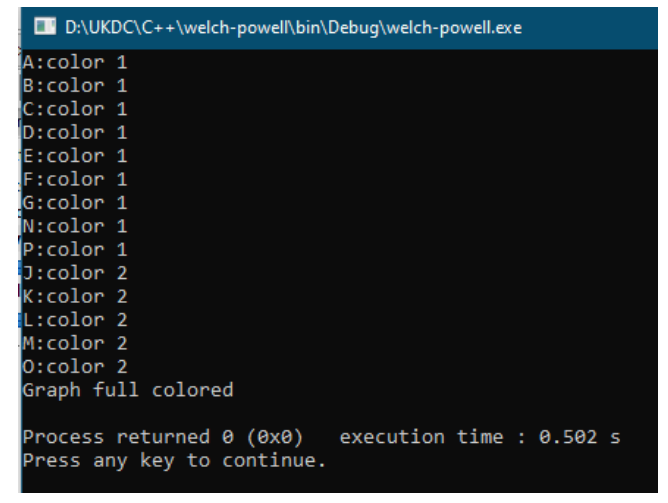

Gambar 6. Hasil eksekusi program dengan algoritma welch-powell

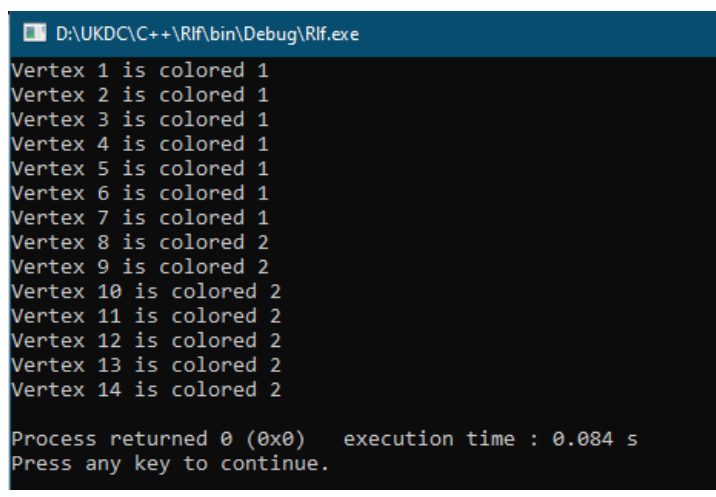

Gambar 7. Hasil eksekusi program dengan algoritma recursive largest first

Tabel 3

Hasil Pengujian Algoritma welch-powell dan recursive largest first

\begin{tabular}{|c|c|c|c|c|c|}
\hline \multirow{3}{*}{ Algoritma } & \multicolumn{5}{|c|}{ Parmeter Penguji } \\
\hline & \multicolumn{4}{|c|}{ Waktu Pengeksekusian (detik) } & \multirow[b]{2}{*}{$\begin{array}{l}\text { Kompl } \\
\text { eksitas }\end{array}$} \\
\hline & $\begin{array}{l}\text { Pengujia } \\
\text { n } 1\end{array}$ & $\begin{array}{l}\text { Penguji } \\
\text { an } 2\end{array}$ & $\begin{array}{l}\text { Penguji } \\
\text { an } 3\end{array}$ & $\begin{array}{l}\text { Rata } \\
\text {-rata }\end{array}$ & \\
\hline $\begin{array}{l}\text { Welch- } \\
\text { Powell }\end{array}$ & 0,055 & 0,071 & 0,122 & $\begin{array}{c}0,08 \\
3\end{array}$ & 98 baris \\
\hline $\begin{array}{l}\text { Recursive } \\
\text { Largest } \\
\text { First }\end{array}$ & 0,162 & 0,110 & 0,049 & $\begin{array}{c}0,10 \\
7\end{array}$ & $\begin{array}{c}168 \\
\text { baris }\end{array}$ \\
\hline
\end{tabular}

Berdasarkan tabel hasil pengujian, algoritma welch-powell lebih cepat dalam waktu pengeksekusian program untuk menyelesaikan permasalahan penjadwalan sebesar 0,083 detik serta memiliki tingkat kompleksitas yang rendah yaitu menghasilkan sebanyak 98 baris kode, dibandingkan dengan algoritma recursive largest first yang memiliki waktu pengeksekusian program sebesar 0,107 detik dan menghasilkan kompleksitas program yang cukup tinggi yaitu sebanyak 168 baris kode, sehingga didapatkan kesimpulan dari tabel pengujian yang telah dilakukan bahwa program dengan kompleksitas yang rendah atau memiliki baris kode yang ringkas mempengaruhi waktu pengeksekusian, dan program dengan implementasi algoritma di dalamnya yang memerlukan waktu lebih singkat dibandingkan dengan program pembandingnya menunjukkan bahwa algoritma tersebut lebih efisien.

Pewarnaan graf yang dapat dibentuk dengan menggunakan algoritma welchpowell

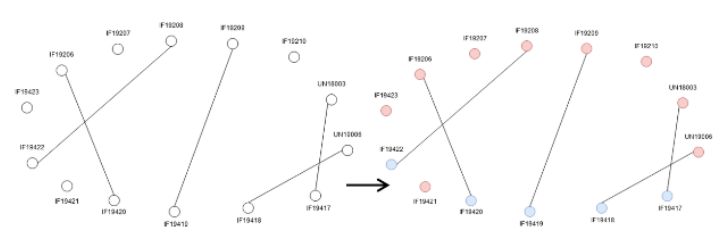

Gambar 8. Hasil pewarnaan graf dengan algoritma welch-powell

Pewarnaan graf yang dapat dibentuk dengan menggunakan algoritma recursive largest first

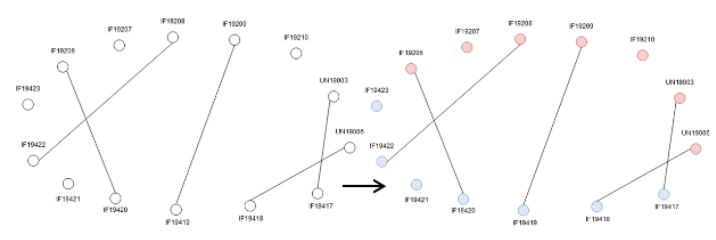

Gambar 9. Hasil pewarnaan graf dengan algoritma recursive largest first

Kemudian berdasarkan hasil dari pewarnaan graf didapatkan bilangan kromatik yaitu 2 (dua) yang dimana berarti dalam sehari yang terdapat 2 jadwal mata 
kuliah dengan waktu yang sama mendapatkan ruang kelas masing-masing sehingga tidak adanya benturan dalam penggunaan ruang kelas, seperti pada tabel jadwal perkuliahan yang dapat dibentuk berikut ini

Tabel 4

Jadwal Ruang Perkuliahan Program Studi Ilmu Informatika Semester 2 dan 4

\begin{tabular}{|c|c|c|c|c|c|c|c|}
\hline \multicolumn{4}{|c|}{ Semester 2} & \multicolumn{4}{|c|}{ Semester 4} \\
\hline $\begin{array}{l}\text { Ko } \\
\text { de }\end{array}$ & Hari & Jam & $\begin{array}{c}\text { Ru } \\
\text { an } \\
\text { ga } \\
\text { n }\end{array}$ & Kode & Hari & $\begin{array}{l}\mathbf{J a} \\
\mathbf{m}\end{array}$ & $\begin{array}{c}\text { Ru } \\
\text { an } \\
\text { ga } \\
\text { n }\end{array}$ \\
\hline $\begin{array}{c}\text { IF } \\
19 \\
20 \\
8\end{array}$ & Senin & $\begin{array}{c}09.4 \\
0 \mathrm{~s} / \mathrm{d} \\
12.1 \\
0\end{array}$ & $\begin{array}{c}\mathrm{R} 0 \\
1\end{array}$ & $\begin{array}{c}\text { IF1942 } \\
2\end{array}$ & Senin & $\begin{array}{c}09 \\
40 \\
\mathrm{~s} / \mathrm{d} \\
12 . \\
10\end{array}$ & $\begin{array}{c}\mathrm{R} 0 \\
2\end{array}$ \\
\hline $\begin{array}{c}\text { IF } \\
19 \\
20 \\
9\end{array}$ & Senin & $\begin{array}{c}13.0 \\
0 \mathrm{~s} / \mathrm{d} \\
15.3 \\
0\end{array}$ & $\begin{array}{c}\mathrm{R} 0 \\
1\end{array}$ & $\begin{array}{c}\text { IF1941 } \\
9\end{array}$ & Senin & $\begin{array}{l}13 . \\
00 \\
\mathrm{~s} / \mathrm{d} \\
15 . \\
30\end{array}$ & $\begin{array}{c}\mathrm{R} 0 \\
2\end{array}$ \\
\hline $\begin{array}{c}\mathrm{U} \\
\mathrm{N} 1 \\
80 \\
03\end{array}$ & Selasa & $\begin{array}{c}09.4 \\
0 \mathrm{~s} / \mathrm{d} \\
11 / 2 \\
0\end{array}$ & $\begin{array}{c}\mathrm{R} 0 \\
1\end{array}$ & $\begin{array}{c}\text { IF1941 } \\
7\end{array}$ & Selasa & $\begin{array}{l}10 . \\
30 \\
\text { s/d } \\
13 . \\
00\end{array}$ & $\begin{array}{c}\mathrm{R} 0 \\
2\end{array}$ \\
\hline $\begin{array}{c}\text { IF } \\
19 \\
20 \\
7\end{array}$ & Selasa & $\begin{array}{c}13.0 \\
0 \mathrm{~s} / \mathrm{d} \\
15.3 \\
0\end{array}$ & $\begin{array}{c}\mathrm{R} 0 \\
1\end{array}$ & $\begin{array}{c}\text { IF1941 } \\
8\end{array}$ & Rabu & $\begin{array}{c}08 . \\
00 \\
\text { s/d } \\
10 . \\
30\end{array}$ & $\begin{array}{c}\mathrm{R} 0 \\
2\end{array}$ \\
\hline $\begin{array}{c}\text { U } \\
\text { N1 } \\
90 \\
06\end{array}$ & Rabu & $\begin{array}{c}09.4 \\
0 \mathrm{~s} / \mathrm{d} \\
11.2 \\
0\end{array}$ & $\begin{array}{c}\mathrm{R} 0 \\
1\end{array}$ & $\begin{array}{c}\text { IF1942 } \\
1\end{array}$ & Rabu & $\begin{array}{l}11 . \\
20 \\
\text { s/d } \\
13 . \\
50\end{array}$ & $\begin{array}{c}\mathrm{R} 0 \\
1\end{array}$ \\
\hline $\begin{array}{c}\text { IF } \\
19 \\
20 \\
6\end{array}$ & Kamis & $\begin{array}{c}10.3 \\
0 \mathrm{~s} / \mathrm{d} \\
13.0 \\
0\end{array}$ & $\begin{array}{c}\mathrm{R} 0 \\
1\end{array}$ & $\begin{array}{c}\text { IF1942 } \\
3\end{array}$ & Kamis & $\begin{array}{l}08 . \\
50 \\
\text { s/d } \\
10 . \\
30\end{array}$ & $\begin{array}{c}\mathrm{R} 0 \\
1\end{array}$ \\
\hline $\begin{array}{c}\text { IF } \\
19 \\
21 \\
0\end{array}$ & Jumat & $\begin{array}{c}11.2 \\
0 \mathrm{~s} / \mathrm{d} \\
13.0 \\
0\end{array}$ & $\begin{array}{c}\mathrm{R} 0 \\
1\end{array}$ & $\begin{array}{c}\text { IF1942 } \\
0\end{array}$ & Kamis & $\begin{array}{l}10 . \\
30 \\
\text { s/d } \\
13 . \\
00\end{array}$ & $\begin{array}{c}\mathrm{R} 0 \\
2\end{array}$ \\
\hline \multicolumn{8}{|c|}{ Keterangan: } \\
\hline \multicolumn{4}{|c|}{ IF19206 = Sistem Operasi } & \multicolumn{4}{|c|}{ IF19417 = Teori Graf } \\
\hline \multicolumn{4}{|c|}{$\begin{array}{l}\text { IF19207 = Algoritma } \\
\text { Pemrograman } 2\end{array}$} & \multicolumn{4}{|c|}{ IF19418 = Pemrograman Web } \\
\hline \multicolumn{4}{|c|}{$\begin{array}{l}\text { IF19208 = Matematika } \\
\text { Diskrit }\end{array}$} & \multicolumn{4}{|c|}{$\begin{array}{l}\text { IF19419 = Interaksi Manusia } \\
\text { dan Komputer }\end{array}$} \\
\hline \multicolumn{4}{|c|}{$\begin{array}{l}\text { IF19209 = Pemrograman } \\
\text { Visual }\end{array}$} & \multicolumn{4}{|c|}{ IF19420 = Metode Numerik } \\
\hline
\end{tabular}

\begin{tabular}{|l|l|}
\hline IF19210= Bahasa Inggris & $\begin{array}{l}\text { IF19421 = Grafika Komputer } \\
\text { dan Pengolahan Citra }\end{array}$ \\
\hline $\begin{array}{l}\text { UN18003 = Kepemimpinan } \\
\text { Pribadi }\end{array}$ & IF19422 = Sistem Multimedia \\
\hline $\begin{array}{l}\text { UN19006 = Bahasa } \\
\text { Indonesia }\end{array}$ & $\begin{array}{l}\text { IF19423 = Dinamika } \\
\text { Kelompok }\end{array}$ \\
\hline
\end{tabular}

\section{SIMPULAN}

Algoritma welch-powell dan algoritma recursive largest first merupakan algoritma yang dapat digunakan dan efektif dalam membuat sebuah penjadwalan perkuliahan. Berdasarkan dari penelitian yang sudah dilakukan algoritma welch-powell lebih cepat dalam segi waktu dan lebih ringkas dalam kompleksitas dibandingkan dengan algoritma recursive largest first, dikarenakan pada graf hasil representasi dari jadwal perkuliahan masih memiliki orde yang kecil. Pada penelitian yang dilakukan didapatkan bilangan kromatik bernilai 2 (dua) yang berarti dapat dibentuk 2 (dua) kelas untuk mata kuliah yang memiliki waktu yang berbenturan atau waktu yang sama.

\section{DAFTAR PUSTAKA}

Bahri, Saeful; Hidayatulloh, T. (2018) 'Penerapan Coloring Graph Pada Sistem Pengingat Dan Penjadwalan Imunisasi Dasar Lengkap', CESS (Journal of Computer Engineering System and Science), 3(2).

Bustan, A. W. and Salim, M. R. (2019) 'PENERAPAN PEWARNAAN GRAF MENGGUNAKAN ALGORITMA WELCH-POWELL UNTUK MENENTUKAN JADWAL BIMBINGAN MAHASISWA (Implementation of Graph Colouring Using Welch-Powell Algorithm to Determine Student Mentoring Schedule) Ariestha', THEOREMS (The Original Research of Mathematics), 4(1), pp. 7986.

Harianto, K. and Eiva Fatdha, T. S. 
(2016) 'Penerapan Pewarnaan Simpul Graf untuk Menentukan Jadwal Ujian Skripsi pada STMIK Amik Riau Menggunakan Algoritma Welch-powell', SATIN - Sains dan Teknologi Informasi, 1(2). doi: 10.33372/stn.v1i2.27.

Hignasari, L. V. (2020) 'Optimasi Sistem Penjadwalan Dengan Implementasi Algoritma Welch Powell Pada Sistem Penjadwalan Customer Service Di Gerai Indosat Ooredoo Cabang Kuta', Jurnal Ilmiah Vastuwidya, 2(1). doi: 10.47532/jiv.v2i1.78.

Mahmudah, M. and Irawati, T. N. (2018) 'Aplikasi Pewarnaan Graf Terhadap Pembuatan Jadwal Ujian Semester di Jurusan Pendidikan Matematika Universitas Islam Jember', Mathematics, 1, pp. 1-10.

Muflikhudin, B. and Pratama, D. (2021) 'TEKNIK PEWARNAAN GRAF PADA PENJADWALAN PIKET OSIS DENGAN ALGORITMA WELCHPOWELL PADA SMP NEGERI 2 KEMRANJEN', FUSIOMA

(Fundamental Scientifc Journal of Mathematics), 1(1), pp. 8-13.

Novian Riskiana Dewi (2020) 'Penerapan Pewarnaan Graf Terhadap Penyusunan Jadwal Seminar Proposal Skripsi di Prodi Pendidikan Matematika UIN Raden Intan Lampung', Buana Matematika : Jurnal Ilmiah Matematika dan Pendidikan Matematika, 10(1). doi: 10.36456/buanamatematika.v10i1.2610.

Sari, P. B., Rachmawati, H. and Akbar, M. (2013) 'Pewarnaan Graph Untuk Penyusunan Jadwal Kuliah Menggunakan Algoritma Recursive Lerge First (Studi Kasus: Politeknik Caltex Riau)', Jurnal Aksara Komputer Terapan, 2(2).

Setia, A. (2011) 'Penyusunan Jadwal Ujian mata Kuliah Dengan Algoritma Pewarnaan Graf Welch powell', Jurnal Dian, 11(1), pp. 68-74.

Sianipar, Y. (2014) APLIKASI PEWARNAAN GRAF TERHADAP PENYUSUNAN JADWALKARYAWAN DI RSUP H. ADAM MALIK MEDAN. UNIMED.

Sugiyono (2013) Metode Penelitian Kuantitatif, Kualitatif, $R \& D$. Bandung: CV. Alfabeta.

Sunarni, T., Bendi, R. K. J. and Alfian, A. (2017) 'Optimasi Penjadwalan Mata Kuliah Menggunakan Pewarnaan Graf’, Prosiding SNTI dan SATELIT, 2017.

Syam, R., Ihsan, H. and Asman, A. (2020)

'Aplikasi Pewarnaan Graf dengan Algoritma Recursive Largest First pada Penjadwalan Mata Kuliah', Journal of Mathematics, Computations, and Statistics, 2(1). doi: 10.35580/jmathcos.v2i1.12461. 